\title{
Particle Lengths of Whitefly-Transmitted Criniviruses
}

H.-Y. Liu, G. C. Wisler, and J. E. Duffus, United States Department of Agriculture-Agricultural Research Service, 1636 East Alisal Street, Salinas, CA 93905

\begin{abstract}
Liu, H.-Y., Wisler, G. C., and Duffus, J. E. 2000. Particle lengths of whitefly-transmitted criniviruses. Plant Dis. 84:803-805.

An improved method for particle length measurement was used for six members of the genus Crinivirus. Particle measurements were conducted with a CCD-72S solid state camera, which was interfaced with a Zeiss EM 109 electron microscope, and analyzed using the analysis 2.1 Image Analysis Software. In comparisons of specimen preparation methods, the leaf dip method is more representative and reproducible than the antibody capture method or preparation from purified virions. Particle length $(\mathrm{nm})$ ranges of whitefly-transmitted criniviruses are: Abutilon yellows virus (AYV), 800 to 850; Cucurbit yellow stunting disorder virus (CYSDV), 750 to 800; Lettuce chlorosis virus (LCV), 800 to 850; Lettuce infectious yellows virus (LIYV), 700 to 750 ; Tomato chlorosis virus (ToCV), 800 to 850; and Tomato infectious chlorosis virus (TICV), 850 to 900 .
\end{abstract}

Additional keywords: Closteroviridae, histogram

A number of whitefly-transmitted viruses with bipartite ssRNA genomes are members of the recently recognized genus Crinivirus in the family Closteroviridae (15). Particle length is an important criterion for classifying closteroviruses into genera. Early classifications of closteroviruses were based on particle lengths: long types with particles from 1,200 to 2,000 $\mathrm{nm}$ and short types with particles from 700 to $800 \mathrm{~nm}(6,12)$. The measurements were, however, made by a number of different individuals utilizing different techniques and/or criteria for measurement, i.e., modal lengths, average lengths, or even the longest length observed. Lettuce infectious yellows virus (LIYV), for instance, was reported to have particles ranging from 400 to $500 \mathrm{~nm}$ to particles 1,800 to $2,000 \mathrm{~nm}$ (8). Particles of Tomato infectious chlorosis virus (TICV) have been reported with an average length of $645 \mathrm{~nm}$, a modal length of $850 \mathrm{~nm}$, and longest particle of $1,600 \mathrm{~nm}$ (9). Other whitefly-transmitted closteroviruses have similar inconsisten-

Corresponding author: Hsing-Yeh Liu E-mail: hliu@pwa.ars.usda.gov

The mention of firm names or trade products in this article does not imply endorsement or recommendation by the U.S. Department of Agriculture over other firms or similar products not mentioned.

Accepted for publication 14 April 2000.

Publication no. D-2000-0517-01R

This article is in the public domain and not copyrightable. It may be freely reprinted with customary crediting of the source. The American Phytopathological Society, 2000. cies in particle length. Published particle measurement data must be regarded with virus isolation were used. Apparent differcaution because different procedures for

ences may actually be the result of different techniques.

We used the same techniques and criteria to measure the length of several whitefly-transmitted criniviruses (3,811,14,18-20). We also examined Beet yellows virus (BYV) and Citrus tristeza virus (CTV), two known aphid-transmitted closteroviruses, and compared the lengths of all by parallel preparation and measurements to ensure consistency in particle measurements to provide information for closterovirus taxonomy.

\section{MATERIALS AND METHODS}

Viruses. The viruses were whiteflytransmitted criniviruses including Abutilon yellows virus (AYV), Cucurbit yellow stunting disorder virus (CYSDV), Lettuce chlorosis virus (LCV), Lettuce infectious yellows virus (LIYV), Tomato chlorosis virus (ToCV), and Tomato infectious chlorosis virus (TICV). All viruses were
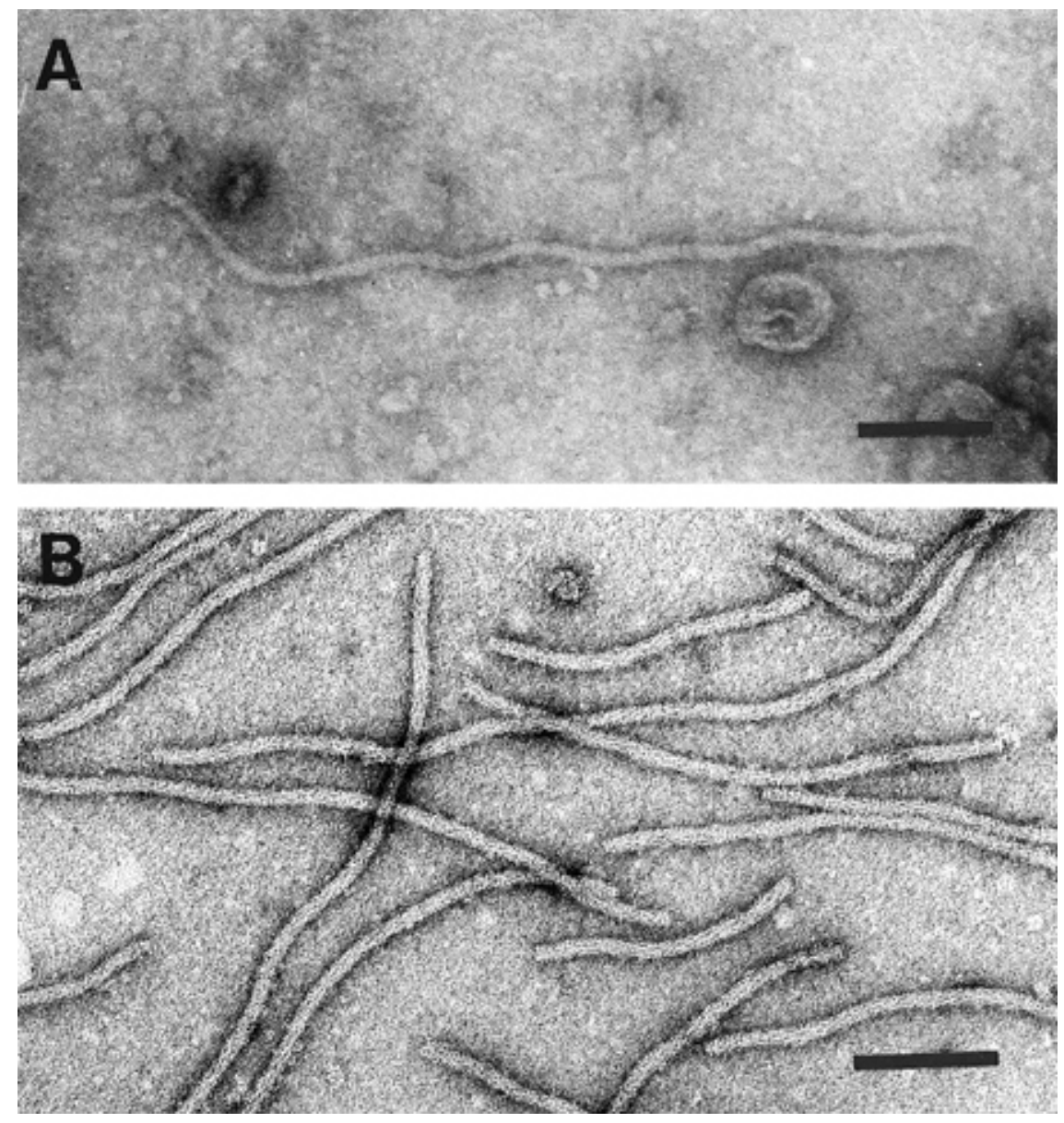

Fig. 1. Electron micrograph of Lettuce infectious yellows virus particles stained in $2 \%$ uranyl acetate. (A) From leaf-dip preparations. (B) From purified virions. Bars represent $100 \mathrm{~nm}$. 
maintained in Nicotiana clevelandii plants in the greenhouse except CYSDV, which was maintained in cucumber (Cucumis sativus) plants and transferred from plant to plant via inoculation with the appropriate whitefly vector (18). Aphid-transmitted BYV was maintained in sugar beet (Beta vulgaris) and transferred from plant to plant via inoculation with the green peach aphid, Myzus persicae. CTV leaf dip grids were kindly prepared by V. J. Febres, University of Florida.

Table 1. Particle lengths of whitefly-transmitted criniviruses and aphid-transmitted closteroviruses measured from leaf dips

\begin{tabular}{lc}
\hline Virus & ${\text { Length }(\mathbf{n m})^{\mathbf{a}}}^{\text {Whitefly transmitted }}$ \\
$\quad$ Abutilon yellows & $800-850$ \\
Cucurbit yellow stunting & $750-800$ \\
disorder & \\
Lettuce chlorosis & $800-850$ \\
Lettuce infectious yellows & $700-750$ \\
Tomato chlorosis & $800-850$ \\
Tomato infectious chlorosis & $850-900$ \\
Aphid transmitted & \\
Beet yellows & $1,200-1,300$ \\
Citrus tristeza & $1,900-2,000$ \\
\hline
\end{tabular}

${ }^{a}$ Particle lengths represent the highest peak range of particles measured on histogram.
Virus purification. Virions were purified using modifications of methods used for TICV (9). Two homogenization methods compared were (i) a VirTis 60 homogenizer for 3 min and (ii) a ball mill for $2 \mathrm{~h}$ at $4^{\circ} \mathrm{C}$. LIYV and TICV virions were purified from $N$. clevelandii plants. CYSDV virions were purified from melon (Cucumis melo cv. Dublon) plants.

Specimen preparation. Leaf dips. One square centimeter of virus-infected plant tissue was ground in $100 \mu \mathrm{l}$ of $0.1 \mathrm{M}$ Tris$\mathrm{HCl}, \mathrm{pH} \mathrm{7.4,} \mathrm{with} 10 \%$ sucrose with a sterilized mortar and pestle. The leaf extracts were transferred to carbon-coated Formvar grids and held for $1 \mathrm{~min}$. After washing the grids with 30 drops of distilled water, grids were stained with $2 \%$ uranyl acetate containing $250 \mu \mathrm{g}$ of bacitracin per $\mathrm{ml}$ (4).

Antibody capture of LIYV particles. Polyclonal antibody, anti-LIYV, was diluted in phosphate buffered saline $(0.02 \mathrm{M}$ phosphate buffer, $\mathrm{pH} 7.0$, with $0.8 \% \mathrm{NaCl}$ ) at 1:1,000 and allowed to bind to Formvarcarbon coated grids for $10 \mathrm{~min}$ at room temperature. After washing three times with distilled water, the specimen preparations were same as leaf dips.

Purified virions. One drop of purified virions was transferred to carbon-coated
Formvar grids, held for $1 \mathrm{~min}$, and then stained as above.

Particle measurement. Negatively stained specimens were viewed with a Zeiss EM 109 electron microscope. Particle measurements were conducted with a CCD$72 \mathrm{~S}$ series solid state camera (Dage-MTI, Inc., Michigan City, IN), which was interfaced with the microscope, and were analyzed using the analysis 2.1 Image Analysis Software (Soft-Imaging Software Corp., Golden, CO). More than 200 particles were measured from each sample.

\section{RESULTS}

The six whitefly-transmitted crinivirus particle lengths ranged from 700 to $900 \mathrm{~nm}$ (Table 1). Particles of the aphid-transmitted BYV and CTV were 1,200 to $1,300 \mathrm{~nm}$ and 1,900 to $2,000 \mathrm{~nm}$, respectively.

Particle length distributions from leaf dips and purified virions are shown in Figures 1,2, and 3. The modal lengths from leaf dips were similar to those from purified preparations when samples were homogenized with the ball mill (Figs. 2A and $\mathrm{C}$, and $3 \mathrm{~A}$ and $\mathrm{B}$ ). When the VirTis 60 homogenizer was used, the particle lengths were widely distributed, with no distinct peak (Fig. 2B).

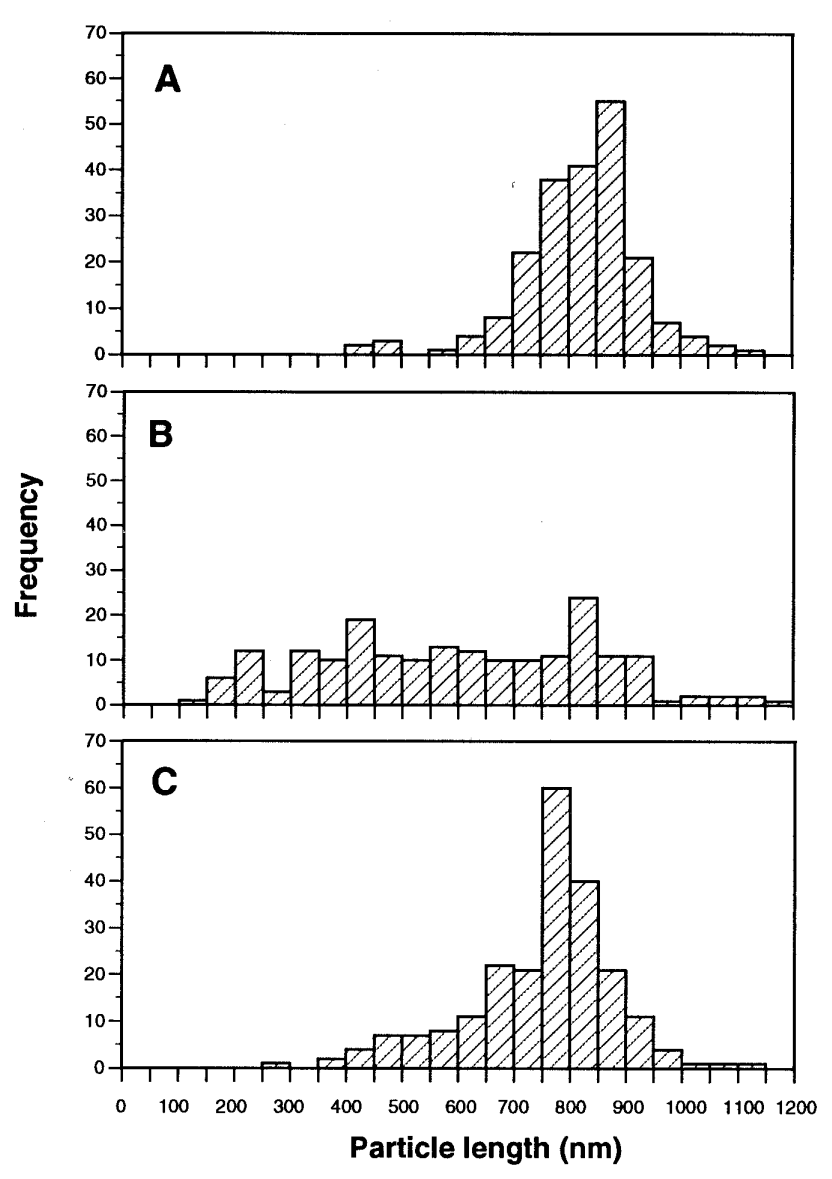

Fig. 2. Particle length distributions of Tomato infectious chlorosis virus (A) in leaf dip preparations. Purified virions extracted with (B) a VirTis 60 homogenizer or (C) a ball mill.

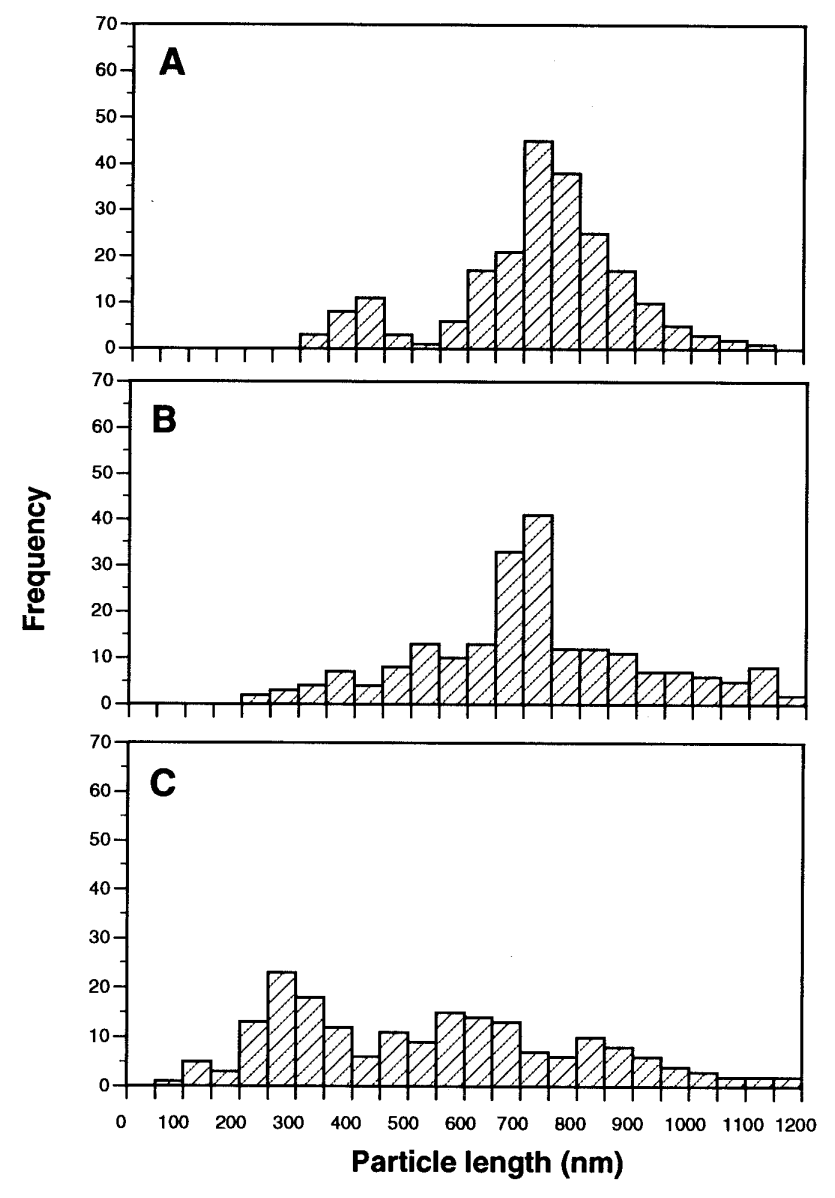

Fig. 3. Particle length distributions of Lettuce infectious yellows virus (A) in leaf dip preparations. (B) Purified virions using ball mill for extraction. (C) Antibody captured method. 
Particle length distributions of polyclonal antibody captured LIYV virions from leaf dips were evenly distributed and apparently captured more shorter particles than those of leaf dips alone (Figs. 3A and C).

\section{DISCUSSION}

Classification of closteroviruses has changed significantly in recent years and continues to change as more members are discovered. Since members of the Closteroviridae are divided into two genera based on particle length and a bipartite ssRNA genome $(6,12)$, consistency in particle measurements is essential for characterization.

Our results confirm that whitefly-transmitted bipartite crinivirus particles are shorter than particles of aphid-transmitted monopartite closteroviruses, as would be expected from a divided genome (17). Our results on particle lengths of BYV and CTV confirm those of previous reports $(1,2)$.

Because the long, flexuous rod particles break during purification due to stresses such as mechanical chopping, osmotic and $\mathrm{pH}$ changes, the modal lengths of particles from leaf dips are longer than those from purified virions. Where the VirTis homogenizer was used for extraction, the virus particles were mechanically broken, resulting in evenly distributed particle lengths (Fig. 2B).

A method for the detection and identification of viruses that uses electron microscope grids coated with an adsorbed film of antiserum specific for a given virus has been used (5). This method is very useful for identifying viruses from leaf dips, especially for those viruses of low concentration in plant sap. However, for particle length measurements, this antibody trapping method absorbed the shorter particles on the grids (Fig. 3C) that were not representative of the range or mode of particle lengths for the virus found in our assays.

Although criniviruses are bipartite (15), two peaks were not observed to represent the particle lengths for RNA 1 and 2. This is likely because particle lengths corresponding to RNA 1 and 2 are very close in size.

AYV (14) is transmitted by the bandedwing whitefly (Trialeurodes abutilonea), and its particle length ranges from 800 to $850 \mathrm{~nm}$. AYV was recently shown to be bipartite (H.-Y. Liu, unpublished data). LCV (10) has not been shown to be bipartite (16), although it is whitefly-transmitted, and its particle length ranges from 800 to $850 \mathrm{~nm}$. Beet pseudo-yellows virus (BPYV) is transmitted by the greenhouse whitefly (T. vaporariorum) $(7,13)$. Because of its low titer in the infected plant, it is difficult to obtain enough particles for a good histogram. However, more than 20 BPYV particle length measurments were between 600 and $850 \mathrm{~nm}$. Whitefly-transmissibility, particle length, and other closterovirus characteristics suggest that AYV, LCV, and BPYV might be members of the new genus Crinivirus.

\section{ACKNOWLEDGMENTS}

We thank B. W. Falk and A. V. Karasev for their critical review of the manuscript and V. J. Febres for providing Citrus tristeza virus leaf dip grids. We thank Ling Ling Jia, A. A. Cortez, J. L. Sears, and K. O. Schlueter for their excellent technical assistance.

\section{LITERATURE CITED}

1. Bar-Joseph, M., and Lee, R. F. 1989. Citrus tristeza virus. CMI/AAB Descriptions of Plant Viruses, No. 353.

2. Bar-Joseph, M., and Murant, A. F. 1982. Closteroviruses. CMI/AAB Descriptions of Plant Viruses, No. 260.

3. Celix, A., Lopez-Sese, A., Almarza, N., Gomez-Guillamon, M. L., and RodriguezCerezo, E. 1996. Characterization of cucurbit yellow stunting disorder virus, a Bemisia tabaci-transmitted closterovirus. Phytopathology 86:1370-1376.

4. Christie, S. R., Purcifull, D. E., Crawford, W. E., and Ahmed, N. A. 1987. Electron microscopy of negatively stained clarified viral concentrates obtained from small tissue samples with appendices on negative staining techniques. Institute of Food and Agricultural Sciences, University of Florida, Gainesville. Bull. 872.

5. Derrick, K. S. 1973. Quantitative assay for plant viruses using serologically specific electron microscopy. Virology 56:652-653.

6. Dolja, V. V., Karasev, A. V., and Koonin, E. V. 1994. Molecular biology and evolution of closteroviruses: Sophisticated build-up of large RNA genomes. Annu. Rev. Phytopathol. 32:261-285.

7. Duffus, J. E. 1965. Beet pseudo-yellows virus, transmitted by the greenhouse whitefly, Trialeurodes vaporariorum. Phytopathology 55:450-453.

8. Duffus, J. E., Larsen, R. C., and Liu, H. Y. 1986. Lettuce infectious yellows virus - A new type of whitefly transmitted virus. Phytopathology 74:97-100

9. Duffus, J. E., Liu, H. Y., and Wisler, G. C. 1996. Tomato infectious chlorosis virus - A new clostero-like virus transmitted by Trialeurodes vaporariorum. Eur. J. Plant Pathol. 102:219-226.

10. Duffus, J. E., Liu, H. Y., Wisler, G. C., and Li, R. H. 1996. Lettuce chlorosis virus - A new whitefly-transmitted closterovirus. Eur. J. Plant Pathol. 102:591-596.

11. Klaassen, V. A., Boeshore, M. L., Koonin, E. V., Tian, T., and Falk, B. W. 1996. Genome structure and phylogenetic analysis of lettuce infectious yellows virus, a whitefly-transmitted, bipartite closterovirus. Virology 208:99110.

12. Lister, R. M., and Bar-Joseph, M. 1981. Closteroviruses. Pages 809-844 in: Handbook of Plant Viruses Infections and Comparative Diagnosis. E. Kurstak, ed. Elsevier/NorthHolland Biomedical Press, Amsterdam, Netherlands.

13. Liu, H. Y., and Duffus, J. E. 1990. Beet pseudo-yellows virus: Purification and serology. Phytopathology 80:866-869.

14. Liu, H.-Y., Li, R. H., Wisler, G. C., and Duffus, J. E. 1997. Characterization of Abutilon yellows virus - A new clostero-like virus transmitted by banded-wing whitefly (Trialeurodes abutilonea). Phytopathology 87:S58.

15. Martelli, G. P., Agranovsky, A. A., Bar-Joseph, M., Boscia, D., Candresse, T., Coutts, R. H. A., Dolja, V. V., Duffus, J. E., Falk, B. W. Gonsalves, D., Jelkmann, W., Karasev, A. V., Minafra, A., Murant, A., Namba, S., Niblett, C. L., Vetten, H. J., and Yoshikawa, N. 1999. Family Closteroviridae. Report of the International Committee on Taxonomy of Viruses, 7th. M. H. V. Van Regenmortel, ed. In press.

16. McLain, J., Castle, S., Holmes, G., and Creamer, R. 1998. Physiochemical characterization and field assessment of lettuce chlorosis virus. Plant Dis. 82:1248-1252.

17. Tian, T., Rubio, L., Yeh, H.-H., Crawford, B., and Falk, B. W. 1999. Lettuce infectious yellows virus: In vitro acquisition analysis using partially purified virions and the whitefly $B e-$ misia tabaci. J. Gen. Virol. 80:1111-1117.

18. Wisler, G. C., Duffus, J. E., Liu, H.-Y., and Li, R. H. 1998. Ecology and epidemiology of whitefly-transmitted closteroviruses. Plant Dis. 82:270-280.

19. Wisler, G. C., Duffus, J. E., Liu, H.-Y., Li, R. H., Simone, G. W., and Hochmuth, R. C. 1996. A new, whitefly-transmitted virus infecting tomato from Florida. Phytopathology 86:S71-S72.

20. Wisler, G. C., Liu, H.-Y., Klaassen, V. A., Duffus, J. E., and Falk, B. W. 1996. Tomato infectious chlorosis virus has a bi-partite genome and induces phloem-limited inclusions characteristic of the closteroviruses. Phytopathology 86:622-626. 